\title{
The Role of The Government in The Number of Workers Experiencing Layoffs During the Covid-19 Pandemic
}

\author{
Elvira Fitriyani Pakpahan ${ }^{1}$, Meilinda Anwar ${ }^{2}$, Marcellina Riyo Harris ${ }^{3}$, Angel Ong Tama ${ }^{4}$ \\ \{elvirapakpahan@unprimdn.ac.id ${ }^{1}$, meilindaanwarr@gmail.com ${ }^{2}$ \} \\ Faculty of Law, Universitas Prima Indonesia \\ Sekip Street, Across Sikambing, Medan, North Sumatera - 20111
}

\begin{abstract}
The Ministry of employment noted that until July 31, 2020, the number of workers affected by layoffs and being laid off had reached more than 3.5 million as the result of Covid-19 pandemic. This research aims to analyze the role of the government in the number of workers experiencing layoffs during the Covid-19 pandemic in the city of Medan. This research uses empirical juridical method. The conclusion obtained from this study is that the central and local governments have made various efforts in handling the Covid-19 pandemic, including: Stay at Home Policy, Work from Home, Health Protocol "The New Normal", Implementation of Health Protocols with Big Scale Social Restrictions, Pre-Employment Card Program, and Socio-Economic Policy Package. The efforts of the Medan city government in dealing with the many cases of layoffs in companies have also been carried out, namely referring to the central government policy.
\end{abstract}

Keywords: Government; Labor; Work Termination; and Covid-19

\section{Introduction}

Corona Virus Diseases is a new term created in December 2019, as how the world pandemic is referred by World Health Organization (WHO). Corona Virus Diseases were caused by viruses that were transmitted from animals to humans. This virus was known to originate in Wuhan City, China, in December 2019. On June 1, 2020, the virus had spread in 216 countries, including Indonesia. Confirmed death cases were reported to be as high as 1.641, infected victims totalled 26.940, and patients who recovered as many as 7.637. Regional Government Budget in Medan was also affected by the Covid-19 pandemic. In 2020, the budget had decreased as low as $40 \%$. The budget reduction came from the Central Government General Allocation Fund. Revenue Sharing Fund as well as region own Source Revenue from North Sumatera Provincial Government had also seen a decline. Due to the reduction in funds, many development programs, which the government had planned prior, had to be foregone.

In addition, the spread of Covid-19 had caused economic instability; hence, exchange rate and capital transactions underwent a deficit. Regional Government Budget had been allocated to handle Covid-19 cases. This condition didn't only affect Medan, but also all regions in Indonesia. Ministry in Manpower recorded that the number of laid-off employees had reached more than 3,5 million on July 31, 2020. According to collected data by BPJS Ketenagakerjaan, a public legal body tasked to protect workers, as many as 2,1 million 
employees were retrenched. This pandemic affected the national economic system and impacted Indonesian workers in four sectors - tourism, manufacture, trade, and agriculture.

As a state apparatus, the government should concern the national economy so it will not endanger national security; therefore, the government has responsibilities in the employment sector to ensure the constitution be held fair for all sides as it should be. To guarantee justice in implementing the statutory rules, the government steps in handling employee layoffs. (Rahayu, 2019).

According to Yustisia (2015), there are a few types of layoffs between the employer and the employee, one of them is caused by the employer's termination. Several reasons that may cause that include:

a. The employee errs or makes a terrible mistake

Work termination towards a worker who makes a mistake is regulated in Employment Law Number 13 of 2020 article 158. Detrimental acts such as embezzling, stealing, or other actions.

b. Absent worker

Terminating work towards an absent worker is regulated in Employment Law article 168. When an employee does not attend work for doing work rallies, those which are not suitable with the law, he/she is considered absent. Meanwhile, if an employee does not go to work because of doing a strike, one suitable with the law, he/she can't be considered absent.

c. Amalgamation, status change, merger, or acquisition

It is not uncommon for entrepreneurs when running their companies to face a situation where they must make a decision that is related to the merger, acquisition, and company status change for the sake of business continuity. However, sometimes the decision may affect their employees, for example, work termination.

d. The company has closed down due to continued losses for two consecutive years or coercive circumstances (force majeure) Based on Employment Law article 61 letter (d), coercive circumstances are defined as a certain incident such as a natural disaster, riot, or security disturbance. When things get tough, achievement fulfilment is not possible - or hindered. Meanwhile, when a change is present, it may be harder to meet an agreement. If it continues nevertheless, one of the sides will suffer from a loss.

e. The company shuts down to improve efficiency.

Implemented in article 164 letter (3), a customer agrees on a work contract according to company rules based on mutual cooperation.

f. Worker with prolonged illness or disability due to workplace accident.

An employee who suffers from a prolonged disease, disability caused by work accident, and is unable to work for more than 12 months may propose work termination. In addition, the employer who terminates the contract with that worker must provide him/her with severance pay twice as much the original amount. This is strictly regulated in article 156 letter 2.

According to Pakpahan (2017), one of the three main development pillars aside from social and politics is economy. Currently, developing country is focusing on national development, especially on human quality, and the Indonesian who are eager for competing to global issues. One of researches regarding work termination in Covid-19 situation has been conducted by Juaningsih (2020), who researched about termination policy for former employees in the Covid-19 pandemic situation in Indonesia. The result showed that work termination during the Covid-19 pandemic which were used as alibis by several companies were deemed illogical, as some companies argued with force majeure. This reason cannot be 
categorized as an outbreak that is currently happening in Indonesia, where Covid-19 is not categorized as a national disaster. Based on Employment Law Number 13 of 2003, if a company loss has not reached 2 years, the company cannot simply terminate the employment agreement. Therefore, another effort from companies or the government in overcoming the impact of Covid-19 on terminated workers need to be done. One of them is limiting work time / overtime and workers can be laid off, so there is no need for termination of employment. Thus, it is expected to help the government reduce unemployment and help grow the economy during the Covid-19 pandemic.

Based on the exposure to the background studied, this study aims to analyse the role of the government in the number of workers who have experienced termination during the Covid-19 pandemic in Medan. This topic is interesting to be used as research material because there has never been any similar research that discusses the role of the government in the rampant layoffs in the midst of the Covid-19 pandemic, especially since this pandemic is the first pandemic that has occurred since Indonesia became independent in 1945.

\section{Research Methods}

This research applies the empirical juridical method. According to Khaleed (2018), the empirical juridical method is also known as socio-legal research. Research using this method is a research that begins with normative research (review) of the laws and regulations followed by in-depth observation and questionnaire distribution in order to obtain non-legal data that is related to and influences the laws and regulations examined in the study.

\section{Results and Discussion}

The spread of the Corona Virus occurred in last March, which then affected economic and social conditions overall. The pandemic has had a huge impact on the cessation of social and economic activities in the community. Large-Scale Social Restrictions (Pembatasan Sosial Berskala Besar in Indonesian) have been done in several areas to prevent the spread of the Covid-19 Virus. (Central Statistics Agency, 2020). The SMERU Research Institute, an independent research institute that conducts research and public studies in Indonesia, released data that there were at least 2 (two) implications of the economic crisis experienced by Indonesia due to the Covid-19 pandemic in the labor sector in July 2020, namely:

1. An increase of unemployment number

The crisis caused workers to be laid off or terminated. The Ministry of Manpower noted that around one million workers were laid off or terminated. However, this data is currently not valid to provide an overview of the number of unemployed as data from the informal sector unemployment has not been obtained and new unemployment forces. Therefore, it is necessary to have data on the overall unemployment rate 


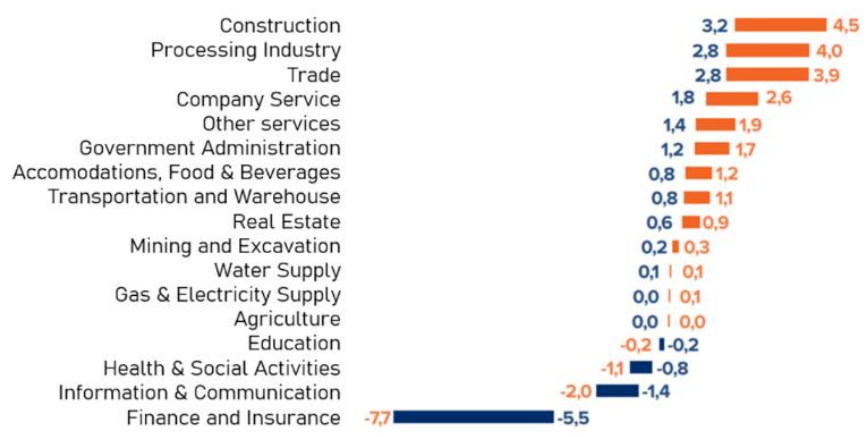

Fig. 1. The spread of unemployment rate in accordance with various sector.

If we analyze the spread (see Figure 1), the trade sector is the sector that causes the most unemployment during the pandemic due to temporary layoffs or termination. The estimation results indicate a shrinkage of the workforce in this sector of around 677,100-953,200 people. However, if the proportion is analyzed, in February 2020, construction is the sector that shows the most labor absorption rate with a proportion of $3.2 \%-4.5 \%$ of the total number of workers in that sector. Despite this, some sectors are expected to provide education, information, and communication services as well as insurance.

2. Post-critical sectoral changes

Another challenge for employment is the potential for changes in the workforce that will occur after the crisis and lead to the exclusion of low-educated and low-quality workers from the formal sector. At least four of these factors will help with this phenomenon:

a. Labor absorption will not be as large as the number of terminated workers.

b. Companies can employ workers who have high productivity and are able to multitask. For example, a hotel business will only employ workers who have managerial skills and can serve guests in the restaurant section.

3. The business sector that has developed post-pandemic is technology-related business.

4. Subcontracting system and workers contracted for entrepreneurs because of the relatively high flexibility over companies with workers.

The Covid-19 pandemic has had a major impact on the labor sector. From the data collected by various institutions, it is known that the number of workers who were dismissed was higher than those who experienced layoffs. The government appealed to companies that layoffs that were carried out were the last resort in dealing with the impact of Covid-19. There are several ways that companies can do to prevent layoffs, for example, by reducing workdays, working hours, work shifts, and temporarily resting or laying off employees.

There are several government programs that have been carried out in dealing with the impact of the Covid-19 pandemic in Indonesia, including:

\section{Stay at Home, Work from Home Policy.}

The work from home policy during the Covid-19 pandemic can be linked to the provisions of Article 86 paragraph (1) letter a of Employment Law Number 13 of 2003. Therefore, company directors can take over the prevention of the risk of massive transmission of Covid-19.

These preventive measures can be grouped as follows:

a. For the time being, the company can reduce some of its business activities, for example: part of its time, employees and operating expenses. 
b. Companies that cannot stop their business activities due to direct activities related to health services, basic needs, and oil fuels.

c. For the time being, the company can choose to suspend all of its business activities

\section{Health Protocol "The New Normal".}

New Normal is a policy to reopen socio-economic activities as well as public activities that are limited by taking into account health protocols. This is done to restore the lives of the people on average with a new habit as an effort to save the lives of citizens and to protect the nation so that it can remain capable of leading its obligations. This was done after the policy of stay-at-home, work-from-home, and large-scale social restrictions to prevent the massive spread of the Covid-19 virus. New Normal is still being carried out because the virus vaccine is still not available, while the country's economy and society must continue to run. This policy was carried out because community couldn't continue hiding in the house without certainty, the economy of the community would be halted which would result in bankruptcy, mass layoffs, and social chaos. The New Policy has normally been carried out with full awareness that epidemics are still around the community.

Therefore, all public activities will be permitted with conditions following the prescribed health protocols. The policy was implemented because no citizen was able to survive by just living at home without any income to pay for their needs. Every human being needs food and supports their family members. The new-normal policy is a solution carried out in order to deal with the pandemic that is still unknown for its extension period. This policy is aligned with the protection and security program for people in need and without reducing the focus on providing health services in handling victims of the Covid-19 pandemic, including the following:

a. Etiquette for cleaning hands with soap or a handsanitizer is in accordance with proper hand hygiene prochedures.

b. Wear masks often when doing activities outside the house. Medical masks are used for those with coughs, flu and laryngitis. Cloth masks are used for healthy people. N95 masks are used for medical personnel who are in direct contact with Covid-19 patients.

c. Avoide crowded or mass gathering places.

d. Physical distancing by keeping a minimum distance of 2 meters.

e. Thoroughly process and warm food.

f. Avoid direct contact with animals.

g. Avoid wearing and sharing personal items with others.

h. Avoid shaking hands with other people.

i. Avoid unnecessary travels

j. Consult a health worker or doctor if there are symptoms immediately.

\section{Pre-Employment Card Program.}

The pre-employment card program is a program developed by the government for workers to assist workers who have experienced termination. This program consists of assistance for training costs and income for workers, including small companies, whose purchasing ability has decreased as a result of the impact of this virus pandemic. The preemployment card program is designed with the aim of both manpower and microentrepreneurs to improve the performance and competitiveness of workers and to help develop entrepreneurship for micro-entrepreneurs. 
The Pre-Employment Card Program aims to:

1. Increase the workforce.

2. Increase productivity as well as workforce.

3. Develop entrepreneurship.

Initially, the Pre-Employment card was intended to provide vocational training to improve competence. However, during the Covid-19 pandemic, the government changed the Pre-Employment Card from training to an incentive in the form of social security or a social safety net. The application of this program has also been accelerated to prevent termination. This is aimed for laborers whose income have decreased as a result of this pandemic.

The Pre-Employment Card is not only intended for people looking for work, but also for workers who have been laid off and need to improve their work skills, for example, workers who are not wage earners and workers who are sent home. All Indonesian citizens who are at least 18 years of age and currently not attending normal education can enroll in this program. The Pre-Employment Card Program is prioritized for workers who are laid off as well as micro-business entrepreneurs who are directly affected.

\section{Socio-Economic Policy Package.}

The socio-economic policy package is a positive response by the government, for example, reducing electricity bills, providing basic foodstuffs, and restructuring credit. All government policy packages mentioned above are very influential in the labor sector. In its implementation in various regions in Indonesia, the majority of regions also apply this policy because the policy package above applies nationally. However, in practice, regional governments have regional autonomy to make policies and stimuli that are most suitable for their respective regions.

In Medan, all of those policy packages have been implemented, although there are still several other specific policies, including:

\section{Cluster Isolation Policy}

In implementing Cluster Isolation, the Medan City Government will conduct a screening for the people who come to Medan. Furthermore, body temperature check will be done. If the body heat reaches $38^{\circ} \mathrm{C}$, that person is required to carry out self-quarantine at home because it is categorized as people under surveillance. Even though it is classified as people under surveillance, it cannot be concluded that this person is positive for the Covid-19 virus. However, to avoid local transmission, the person should carry out self-quarantine at home. During the quarantine period, the person will be provided with food assistance from the government. Apart from people under surveillance, self-quarantine at home will also be applied to people who fall into the category of people without symptoms and travelers.

2. Issued Mayor Regulation Number 11 of 2020

This rule contains the health quarantine policy, which is to do quarantine for travelers, people without symptoms, and people under surveillance. From the results of observations and data collected from various media, several things that have been done by the government in handling workers in the city of Medan during the Covid-19 pandemic, are as follows:

a. The Medan city government does not impose Large-Scale Social Restrictions as in Jakarta; however, it is still an appeal from the government to not leave the house if there is nothing urgent, keep your distance, diligently wash your hands, avoid crowds and use a mask when leaving the house.

b. The concept of handling carried out by the Medan City Government is to prepare a physical treatment, namely by preparing a hospital and completing all the medical equipment needed to treat patients exposed to the Covid-19 virus until they recover. 
c. The concept of handling in a non-physical form is carried out by preparing for the social impacts of the Covid-19 pandemic. Because the community has experienced a decrease in income, many have lost their livelihoods. The North Sumatra Provincial Government has prepared a fund of Rp. 1.5 trillion in the form of refocusing and budget reallocation, including social assistance for communities affected directly by the pandemic.

\section{Conclusion}

From the description of the results and discussion above, the conclusion that can be drawn from this study is that the central and local governments have made various efforts to deal with the Covid-19 virus, including policies at home, working from home, health protocol "The New Normal", pre-employment cards and socio-economic policy packages

The efforts of the Medan city government in dealing with the many cases of layoffs in companies have also been carried out, namely referring to the central government policy. One of the most influential policies on the employment sector is the Pre-Employment card program. This program is an assistance program in the form of training costs and incentives for workers, workers who have been terminated / workers who have been laid off, job seekers, and minor business workers who have lost their jobs and / or experienced a decrease in purchasing due to the Covid-19 pandemic and workers who have improved their Program Skills.

The Pre-Employment Card aims to develop workforce competence, increase labour productivity and competitiveness, along with entrepreneurship. The handling of the Covid-19 pandemic is not perfect because there are still many weak points. For example, the lack of quick response from the government regarding weaknesses in data accuracy and coordination, which is highly expected in improving the implementation of the current assistance policy, apart from working from home, this policy is implemented in the interests of the community but there are still many challenges and obstacles. Because not all work sectors can be done at home, such as the absence of work tools and communication, lack of coordination, disturbance of the "domestic" environment in the household, and finally the Pre-Employment card program, this policy is deemed ineffective in anticipating the wave of layoffs.

It is feared that this problem can affect the level of community welfare. With the PreEmployment card, there is not much help because what workers need right now is actual assistance funds, not a form of training. Pre-employment card funds should be used for other things during this pandemic that still affect people's income. In its implementation, funds must be carried out quickly so they will not lose the distribution, thereby accelerating the handling of the country's weakening economy.

\section{References}

[1] Yustisia, T.V.: Buku Pintar Pekerja Terkena PHK. Jakarta, Visimedia (2015)

[2] Riyanto, S \& Hatmawan, A.A.: Metode Riset Penelitian Kuantitatif Penelitian di Bidang Manajemen, Teknik, Pendidikan dan Eksperimen. Yogyakarta, Penerbit Deepublish (2020)

[3] Miles, M.B., Huberman, A.M., \& Saldana, J.: Qualitative Data Analysis: A Methods Sourcebook. Fourth Edition. New York, Sage Publications, Inc. (2019)

[4] Khaleed, B.: Legislative Drafting, Teori dan Praktik Penyusunan Perundang-undangan. Yogyakarta: Penerbit Medpress Digital (2018) 
[5] Maringan, N.: Tinjauan Yuridis Pelaksanaan Pemutusan Hubungan Kerja (PHK) Secara Sepihak oleh Perusahaan Menurut Undang-Undang No. 13 Tahun 2003 Tentang Ketenagakerjaan. Jurnal Ilmu Hukum Legal Opinion, Edisi 3, Vol. 3 (No.3), pp.45-46. E-ISSN: 2541-1594 (2015)

[6] Zaini, A.: Pengaturan Pemutusan Hubungan Kerja (PHK) Menurut Peraturan PerundanganUndangan Ketenagakerjaan. Jurnal UIN Sultan Maulana Hasanuddin Banten, Vol.13 (No.1), pp1721. ISSN: 2656-3096 (2017)

[7] Febriani, L.: Analisis Peranan Dinas Tenaga Kerja Dalam Menangani Masalah Pemutusan Hubungan Kerja (PHK) di Kota Pekanbaru. Jurnal Universitas Islam Negeri Sultan Syarif Kasim Riau, Vol.4 (No.2), pp.88-90. ISSN: 2541-3139 (2017)

[8] Fathammubina, R \&Apriani, R. Perlindungan Hukum Terhadap Pemutusan Hubungan Kerja Sepihak Bagi Pekerja. Jurnal Universitas Singaperbangsa Karawang, Vol.3 (No.1), pp.105. EISSN: 2655-7347 (2018)

[9] Juaningsih, I.N.: Analisis Kebijakan PHK Bagi Para Pekerja Pada Masa Pandemi Covid-19 di Indonesia. Adalah: Buletin Hukum dan Keadilan, Vol.4 (No.1), pp.74-89.ISSN: 23384638 (2020)

[10] Fahrunnisa, F., Razak, R. \& Said, A.: Peran Pemerintah Dalam Menangani Konflik Pemutusan Hubungan Kerja Karyawan PT Gunung Mas di Kabupaten Pangkep. Jurnal Administrasi PublikUniversitas Muhammadiyah Makassar, Vol.3 (No.3), pp.62-69. E-ISSN: 2460-643X (2017)

[11] Dewi, I.S.: Peranan Dinas Tenaga Kerja Kota Palembang Terhadap Tenaga Kerja Atas Pemutusan Hubungan Kerja Dampak Covid-19. Jurnal Universitas Muhammadiyah Palembang, Vol.3 (No.1), pp.42-51. ISSN: 1979-0759 (2020)

[12] Pakpahan, E.F.: Analisis Perlindungan Hukum Terhadap Nasabah Bank Yang Telah Dilikuidasi. Jurnal Ilmu Hukum Prima, Vol.1, Issue 1, pp.1-53. ISSN 2088-5288 (2017)

[13] Pakpahan, E.F.: Konsep Perlindungan Hukum Terhadap Wali Amanat di Pasar Modal. Jurnal Hukum Samudera Keadilan, Vol.14 (No.2), Issue 2,pp.302-315. E-ISSN: 2615-7845 (2016)

[14] Leonard, T., Heriyanti \& Pakpahan, E.F.: Legal Protection for Defaulted Bonds Based on Values of Justice. International Journal of Business, Economics and Law, Vol. 11, Issue 4 (Dec.), pp.48-52. ISSN: 2289-1552 (2016)

[15] Pakpahan, E.F.: Rekonstruksi Pengaturan Obligasi di Pasar Modal Indonesia Berbasis Nilai Keadilan. Jurnal Universitas Islam Sultan Agung, Vol. 2 (No.3), pp.56-21. ISSN: 2302-8912 (2017) 